\title{
Conceptualising holiness in the Gospel of John: The en route to and character of holiness (Part 2)
}

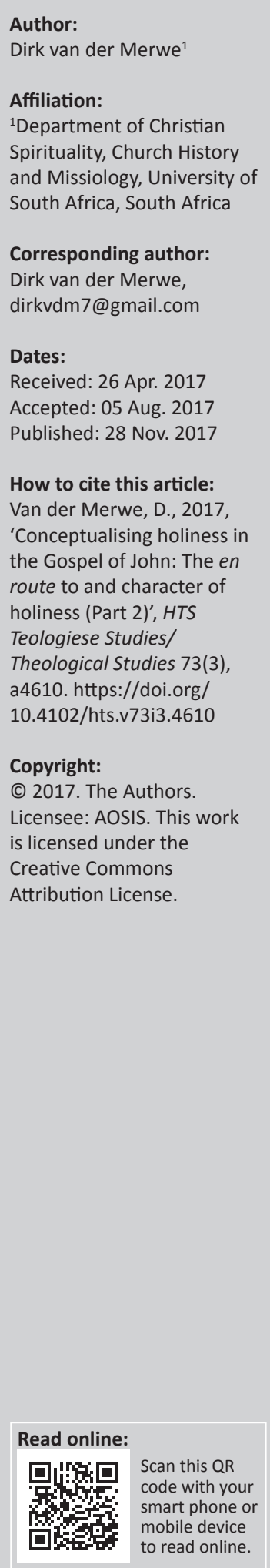

In a previous publication, this author investigated the code as well as the objectives of holiness in the Gospel of John. This research deals with the en route to and character of holiness. The research starts with a concise characterisation of Jesus for the en route and character of holiness is embedded in the character of Jesus. Secondly, reference is made to the mimesis theories of Plato, Aristotle and Ricoeur. This facilitates a better understanding of the en route and character of holiness in John. Thirdly, Jesus could exhorted them to follow him because he has

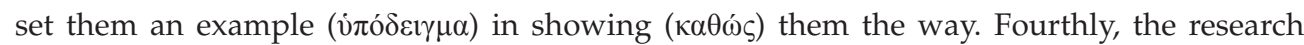
scrutinises those features in John that relate closely to the character of Jesus to provide more light to the en route and character of holiness. Finally, the Spirit ( $\pi \alpha \rho \alpha \dot{\alpha} \lambda \eta \tau$ $\varsigma_{\text {) }}$ will enable and will continue to sanctify the disciples of Jesus. The contribution of this research lies not only in providing a holistic overview of sanctification in John, but also in connecting the en route to and character of holiness in John with the character of Jesus which revolves around his mission of revelation and salvation.

\section{Introduction}

Numerous popular books are published annually to address the issue of holiness as a general popular religious theme. The renewed interest in 'holiness' or 'sanctification' over the past few decades is probably because of the global interest in spirituality and in particular Christian Spirituality. Unfortunately, absolutely nothing has been published academically on 'holiness' or 'sanctification' according to the Gospel of John. In scrutinising the Gospel of John on this topic, one becomes aware how saturated this Gospel is on the teaching about holiness. This article Conceptualising holiness in the Gospel of John: the en route to and character of holiness (part 2) succeeds a previous article with the title, Conceptualising holiness in the Gospel of John: the mode and objectives of holiness, part 1 (Van der Merwe 2017:1-8).

This research will revolve around the following aspects. The next section looks briefly into the identity and character of Jesus in John, for he is the 'holy one of God', the object to be imitated. The 'Sanctification according to John a form of mimesis?' section relates holiness to mimesis as a mimicry of Jesus. In the section entitled 'Jesus exhorts his disciples to imitate him', Jesus could

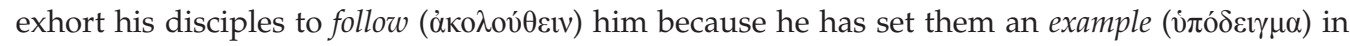

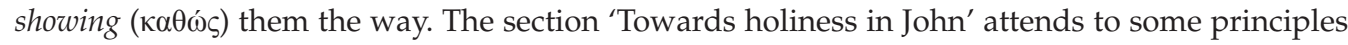
of the en route to holiness embedded in John. Finally, the Paraclete ( $\pi \alpha \rho \alpha \dot{\alpha} \lambda \eta \tau o \zeta)$ enables and continues to sanctify the disciples of Jesus. This approach is legitimised and substantiated by what has been captured in the previous article mentioned above. ${ }^{1}$

\section{Jesus in the Gospel of John}

This subsection briefly explores the identity of Jesus in John for he is the symbol of holiness.

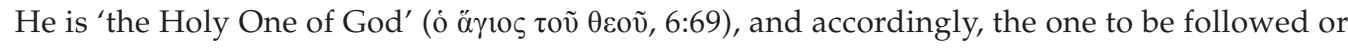
imitated. Looking at his humanity, he is called a teacher $(1: 38 ; 3: 2,9 ; 9: 1 ; 11: 28 ; 13: 13,14 ; 20: 16)$, Jew $(4: 9 ;$ cf. $18: 33,39 ; 19: 3,19,21)$ and was treated by the Jews as an unadorned man $(5: 16 ; 6: 41$, $42 ; 7: 12,20,30,32,45-49$; etc.). He is identified as a prophet $(4: 19 ; 6: 14,40 ; 9: 17 ;$ cf. 4:44; 7:52) because he spoke on behalf of God and performed miracles $(2: 7-11,18-23 ; 4: 46-54 ; 5: 2-9 ; 6: 2-$ $14 ; 9: 1-12 ; 11: 38-44)$ like those in the Old Testament. He is referred to be the Messiah, which is related to a king $(6: 15)$. He is referred to be a king $(1: 49 ; 18: 33,37,39 ; 19: 3,12,14,15,19,21$; cf. 12:13, 15).

1.Conceptualising holiness in the Gospel of John: the mode and objectives of holiness (Part 1) 
In John, this Jesus is also considered to be one with God (the

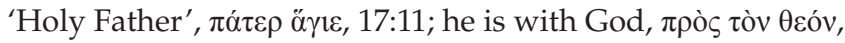
1:1; they are 'in' one another, 17:21-23). Jesus regards God as his Father and himself as the Son of this Father $(1: 18,34$, 49; 3:16-18, 35, 36; 5:19-27; 6:40; 8:36; 10:36; 11:4, 27; 16:13; $17: 1 ; 19: 7 ; 20: 31)$. Throughout John, he uses the phrase 'I am' $(4: 26 ; 6: 35,41,48,51 ; 8: 12,24 ; 9: 5 ; 10: 7,9,11,14 ; 11: 25 ; 14: 6$; $15: 1,5 ; 18: 5,6,8 ;$ cf. $8: 58 ; 13: 19)$ referring to himself that recalls the name of God. When Jesus speaks about himself as the Son of man, it happens to be in the context to reveal the glory of God.

It is crucial that both the above-mentioned natures of Jesus' identity be respected in this research to prohibit any form of distortion of the complete picture and understanding of the en route to and character of holiness. Koester (2008) explains this statement with an excellent comparison:

The phenomenon is like a musical chord. When a musician strikes several notes at the same time, the result is multidimensional sounds. Each note makes its own contribution, and without a particular note, the chord is incomplete. John's presentation of Jesus asks that we listen for the chord, for the human, messianic, and divine tones that together give a multidimensional sense of who Jesus is. (p. 83)

Jesus had one objective in mind and that was to accomplish his mission: 'I glorified you on earth by finishing the work that you gave me to do' (17:4). Four times, Jesus said that his mission is to do the will of his Father who sent him (Jesus) $(4: 34 ; 5: 30 ; 8: 38 ; 8: 29)$. A number of times ${ }^{2}$ he said that he only speaks what the Father told him to say and that he does the work the Father showed him. He gives a summary of his work:

I have made your name known to those whom you gave me from the world. They were yours, and you gave them to me, and they have kept your word. ${ }^{7}$ Now they know that everything you have given me is from you; ${ }^{8}$ for the words that you gave to me I have given to them, and they have received them and know in truth that I came from you; and they have believed that you sent me. (17:6-8)

The reference here to Jesus' absolute obedience to the Father is not to emphasise his act of obedience per $s e^{3}$ rather than through his obedience to the Father he has set his disciples an example to be followed. ${ }^{4}$ During his ministry, Jesus called his disciples to a specific way of life to follow him. This way of life can be called either sanctification, imitating Jesus, discipleship or even doing the will of God. In the Johannine context, they are semantically related and equivalent. The rest of this investigation will look into more detail to the en route of sanctification. John presented Jesus to be equal to the Father to characterise him worthy to be followed, and to be equally a human with whom his followers can identify with.

2.4:34; 5:20, 36; $7: 16 ; 8: 28 ; 9: 3-4 ; 10: 25,31,37 ; 12: 49,50 ; 14: 10 ; 14: 31 ; 17: 4$; also cf. $7: 17$.

3.Care must be taken not to confuse the obedience an agent should display in conveying the message and mimesis. These are two different things.

4.In the acts of Jesus' obedience, a number of meanings are embedded: (1) that he did not sinned by being disobedient, (2) that he accomplished his mission of revelation and salvation, (3) that he has set his disciples an example of obedience to be imitated by them and (4) it refers to the unity that exists between the Father and the Son.
The aspects identified in John to indicate the en route to holiness and the character of holiness relate to the mentality of mimesis. This mental ability will now briefly be discussed in order to contextualise holiness.

\section{Sanctification according to John a form of mimesis? ${ }^{5}$}

According to the above quoted texts that briefly picture and characterise the life of Jesus from John, and more to follow in the rest of the article, it seems that in John, sanctification comprises a form of mimesis. This is explicit (as already pointed out) from the life of Jesus referring a number of times to himself mimicking or mirroring the Father. This is further evident in the many times in his discourses where he uses the subordinating comparative particle $\kappa \alpha \theta \omega \varsigma$ [just as] to refer to the resemblances between the Father's and his activities. He also applies it to his relation with his disciples. In John 13:15, Jesus said to his disciples: 'For I have set you an example, that you also should do as I have done to you' and in John 14:12:

Very truly, I tell you, the one who believes in me will also do the works that I do and, in fact, will do greater works than these, because I am going to the Father

All these reflect a form or a style of mimesis. The Gospel of John is unique in this regard and the only book in the New Testament that refers so numerously to mimicry. Jesus (the 'holy one of God', 6:69) is characterised to emulate God the Father who is holy (17:11). In John 14:11, Jesus says to his disciples, 'Believe me that I am in the Father and the Father is in me; but if you do not, then believe me because of the works themselves'. In John 15:9-10, Jesus says:

As the Father has loved me, so I have loved you; abide in my love. ${ }^{10}$ If you keep my commandments, you will abide in my love, just as I have kept my Father's commandments and abide in his love.

According to Castelli (1991:14), mimesis also appears in the earliest Christian writings. Paul exhorted in his epistles the early Christians to become his imitators. Paul writes, 'Therefore, be imitators of God, as beloved children,' and live in love, as Christ loved us ...' (Eph 5:1-2). Paul promoted beneficial mimicry, too: 'Follow my example, as I follow the example of Christ' (1 Cor 11:1; 1 Th 2:9). ${ }^{6}$ Luke (6:40) writes 'A disciple is not above the teacher, but everyone who is fully qualified will be like the teacher'. Imitating Christ is an unconcealed part of calling to the believers. 1 Peter (1:16) asserts, 'for it is written, "You shall be holy, for I am holy"'. Also, in 1 Peter (2:21), 'For to this you have been called, because Christ also suffered for you, leaving you an example, so that you should follow in his steps'. In 1 John (2:6), the

5.The Merriam-Webster Dictionary (2017) online defines 'mimesis' as: Mimesis is a (2017) online deines 'mimesis' as: Mimesis is a term with an und used in aesthetic or artistic theory to refer to the attempt to imitate or reproduce reality since Plato and Aristotle. 'Mimesis' is derived from the Greek verb
mimeisthai, which means 'to imitate'.

6.In his research on mimesis in the Pauline epistles, she presupposes that the 'notion of mimesis functions in Paul's letters as a strategy of power' (Castelli 1991:14). 
Elder writes, 'whoever says, "I abide in him," ought to walk just as he walked'.

Sörbom (2002:19) widens the occurrence of mimesis. For him, it was a 'fundamental outlook shared by most authors, philosophers and educated audiences in the classical period, in antiquity as a whole, and even later' ${ }^{8}$ The words that were used synonymously with 'mimesis' [imitate] are $\mu$ í $\mu \mu \alpha$ (imitation), દikผóv [image] and ó $\mu$ oí $\omega \mu \alpha$ [likeness]. There are also related terms found in John with semantic-related

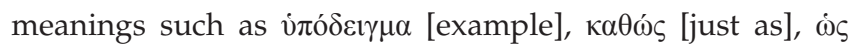

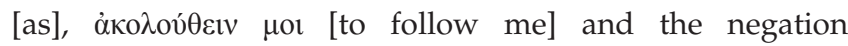
exhortation, غ̇ò̀ $\mu$ í [if ... not].

The two most influential ancient Greek philosophers ${ }^{9}$ Plato and Aristotle and the more contemporary philosopher Paul Ricoeur also have written some thoughts about mimesis. Therefore, it will be wise to confer their thoughts. Plato recognised the pedagogical value of mimesis (Plato, Republic 393c; 396d). ${ }^{10}$ According to him, the emulating of role models causes a child to learn and to mature (Parris 2002:40). ${ }^{11}$ The basic idea behind Plato's use of mimesis is that it functions similarly to a mirror: it reflects or duplicates the already existing (Plato, Republic 596d).

Aristotle methodically improved on Plato's concept of mimesis in three significant ways. Firstly, 'mimesis refers to the recreation, representation or imitation of something that already exists or is known'. Secondly, 'every mimetic act is not a mere copying or reproduction of what already is, but it brings certain facets of what is being represented to light'. Lastly, 'since it is impossible to represent every aspect of an action, the author must select those elements that represent universal traits or qualities that are familiar to the audience' (Aristotle, Poetics 5.5; ${ }^{12}$ also Parris 2002). According to Aristotle, is it pleasurable for a person to identify behaviours or characteristics. ${ }^{13}$

Parris (2002:43) judges Plato's understanding of mimesis as 'a reflection, copying or reproduction' that is assessed by its resemblance to already existing or familiar things. Aristotle diverges from Plato and articulates mimesis not to be simply

7.See also 1 Corinthians $4: 16$; Philippians $3: 17 ; 1$ Thessalonians $1: 6 ; 2: 14 ; 2$ Thessalonians 3:7; Hebrews 6:12; James 5:10-11.

8.For verification of this reference by Sörbom, see footnote 1 of Harrison (2013:213214) of numerous publications on mimesis.

9.This is just an acknowledgement to the work of Parris (2002) who directed me to the thoughts of these three philosophers regarding mimesis.

10.See Plato on mimicry (Plato, Republic 393c-396b; 596d-e). For a more thorough discussion of Plato's thoughts on mimesis, see Nightingale (2006:37-39).

11.See Plato, Republic, Book III: 'but they [children] should not depict or be skilful at imitating any kind of illiberality or baseness, lest from imitation they should come to be what they imitate. Did you never observe how imitations, beginning in early youth and continuing far into life, at length grow into habits and become a second nature, affecting body, voice, and mind?'

12.See Aristotle, Poetics, 1447a; 1447b; 1448a.

13.Aristotle did not associate with negative associations: 'The lawgiver ought therefore to banish indecent talk, as much as anything else, out of the state altogether for light talk about anything disgraceful soon passes into action-so most of all from among the young, so that they may not say nor hear anything of the of all from among the young, so that they may not say nor hear anything of the
sort; and anybody found saying or doing any of the things prohibited' (Aristotle, Politics 1336 b and also 1340 a). a replication, but a creation. ${ }^{14}$ It reflects a new understanding of mimesis. This comprises some literary skills from the writer's side and reasoning from the side of the audience. The author has to show new possibilities and the audience has to recognise the new possibilities to discern what is being presented. Simultaneously, mimesis then enables the audience to observe new opportunities for living (Parris 2002:42). For Aristotle, every mimetic depiction creates a possibility to fabricate a new discernment and new perception of the subject matter. The potential of mimesis occurs in how an author can design a representation of human actions and characters that creatively can present new possibilities of understanding (cf. Parris 2002:43).

More than two millennia later than these two philosophers, Paul Ricoeur reasons about mimesis from a literary perspective. He made a valuable contribution with regard to mimesis in his reference to the dynamic interaction between the text and the reader where the text has influenced the reader. In his book, Time and narrative, under the heading 'Mimesis', Ricoeur refers to mimesis as the acceptance of the text by the reader; this denotes the intersection that occurs between the 'world of the text and the world of the hearer or reader' (Ricoeur 1990 [1983]:71; also Parris 2002:45). With this understanding, Ricoeur (1990 [1983]:46, 53-87) ${ }^{15}$ refines and develops Aristotle's thought about mimesis. This implies that mimesis mediates and navigates between the three components of hermeneutics: author, text and reader.

The occurrence and interpretation of the symbols, metaphors, examples and exhortations of Jesus in John clearly illustrate the recognition and occurrence of mimesis. The characters, discourse and mimesis embedded in the text would have been easily recognised by the audiences of Jesus, in relation to the sociocultural circumstances of their daily living. Themes in John, extracted from the Old Testament, would have been recognised by them in relation to their theology and understanding of the Hebrew scriptures. ${ }^{16}$ The sociocultural circumstances, the audiences share with the content of the Gospel, draw them into the Gospel's mimetic representation and force a comparison with their circumstances. This then allows them to discern about truth, legitimacy and appropriateness of these symbols, metaphors, examples and exhortations of Jesus in their own circumstances (cf. Parris 2002:54).

An important thing always to be considered is that the composition of the text (plot) is built on an ancient world view and within a specific culture. Therefore, for Ricoeur (1990 [1983]:54), there are features such as 'meaningful structures', 'symbolic resources' and 'temporal characteristics' described

14. Harrison (2013:13-14) agrees. According to him, a collision exists between Plato and Aristotle' over the nature of mimesis. He listed extensively literature on the debate between Plato and Aristotle.

15. Ricoeur (1990 [1983]:46) applies mimesis to poetics. He is of opinion that the mimetic activity is enriched when it draws its mimetic activity from its intelligibility which leads the reader from one side of the text to the other through the power of refiguration.

16.The Gospel of John is saturated with Old Testament content, especially the Torah. See Van der Merwe (2013:1-9) for a more detail discussion on this. 
rather than presumed. Nothing is mentioned that requires their reference to be a closed one. If a presented plot requires any imitation of action, then preliminary knowledge and competence are required from the audience. This implies some knowledge and competence for identifying a particular action by means of its fundamental features. Secondly, when any form of imitation requires to elaborate an indicated action, then supplementary competences are required. Thirdly, these articulations of action carry temporal components from which proceeds the capacity of action (Ricoeur 1990 [1983]:54).

The thoughts of Plato, Aristotle and Ricoeur on mimesis help to understand the dynamics of mimesis to better understand the en route to and character of holiness. For the audience of John, it would not have been an obstacle to imitate Jesus, because they would have been familiar with Jesus' teachings, works and customs. Bearing in mind of what Plato, Aristotle and Ricoeur wrote about mimesis, it is clear from the Gospel content that John presented Jesus in such a way that he should be mirrored (according to Plato's view). The audience of the Gospel (and believers today) would also know that for mimetic representation, a new discernment and perception into the subject matter would be required to imitate Jesus in a different time (according to Aristotle's view). In order to achieve this, a contemporary comprehensive hermeneutical approach (according to Ricoeur's view) is needed. ${ }^{17}$ At this point, it must be emphasised that of all the aspects, to be discussed in John that relate to mimesis to articulate sanctification, the literal understanding and application of these aspects are not feasible. All these aspects are liable to creative reinterpretation and conduct for relevant application. Thus, mimesis may not equal exact replication. The disciples must creatively interpret the original teachings and acts of Jesus in order to imitate him (cf. Brennema 2014:265).

One of the main themes in John is that Jesus does nothing independent of the Father. This Father-Son mimesis does not refer to a replicating of God's words and actions. It rather refers to a faithful acting of Jesus on behalf of God. Other instances in John that suggest a disciple-Jesus mimesis also do not have an exact replication in mind. When Jesus sends his disciples into the world 'just as' ( $\kappa \theta \dot{\theta} \varsigma)$ the Father has sent the Son $(17: 18 ; 20: 21)$, the disciples are certainly not sent into the world similar as Jesus by means of the incarnation. When said that his disciples will do the same works as he did ( $\tau \dot{\alpha}$

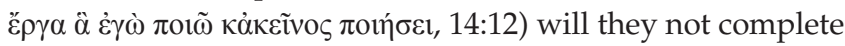
their tasks similar to the task Jesus fulfilled the Father's work to be glorified on the cross. The mimetic imperative of Jesus to his followers 'to lay down their lives' for others as the greatest expression and demonstration of their love (1 Jn 3:16 echoes 15:13) can comprise the exact imitation (cf. 16:2 and 21:18-19), but cannot have the same salvific effect that Jesus had when laying down his life for all (Brennema 2014:273). According to Culpepper (1991:142-144), will the Jesusdisciples mimesis to love one another sacrificially and limitlessly be to the extent that it may ultimately be demonstrable in death (Culpepper 1991:142-144).

17.See the work of Van der Merwe (2015b; 2015c), 'Reading the Bible in the 21st century: some hermeneutical principles' Part 1 and Part 2).
The following aspects assembled in this research about mimesis compliment the understanding of the holiness or sanctification concept in the Gospel of John. From her survey of the ancient discourses on mimesis, Castelli (1991:16) pointed out three aspects of imitation which she thinks the apostle Paul inherited from the Greco-Roman culture: ${ }^{18}$

1. 'Mimesis is always articulated as a hierarchical relationship, whereby the "copy" is but a derivation of the "model" and cannot aspire to the privileged status of the "model";

2. mimesis presupposes a valorisation of sameness over against difference. Certain conceptual equations accompany this move: unity and harmony are associated with sameness while difference is attributed characteristics of diffusion, disorder, and discord;

3. the notion of the authority of the model plays a fundamental role in the mimetic relationship'.

4. Van der Watt (2014:2) points out a fourth aspect referred to by Castelli (1991) later in she discussion of mimesis. She writes that:

This relationship is asymmetrical, for imitation does not involve both elements moving simultaneously toward similarity, but rather one element being fixed and the other transforming itself or being transformed into an approximation of the first. The favored movement is from difference toward similarity. (p. 21)

5. Mack (1995:146) in his discussion of mimesis adds a fifth aspect. He writes, 'To imitate the pattern of an example meant to become like it, to share its character and meaning'. The things to be imitated represent the 'structure, character and the very being of things' (cf. also Van der Watt 2014:3).

6. Hardin (1992:378) refers to Maximus who 'observes that the covetous dynamics of mimesis stem from self-love' (3.56) and states that 'It is mimesis which determines the value of any given object' (4:66). ${ }^{19}$

7. Parris (2002:39), in his effort to explain mimesis, states, 'At its most basic level, mimesis is the mental ability that allows us to imitate or to represent someone or something in our actions, speech, art or literature. At the same time, it also enables us to recognise what the other person is representing'. This implies that most basically, mimesis carries the notion of 'representation, reflection or the image of something' already existing (Parris 2002:40).

Van der Watt (2014:2) makes a critical observation that can be exploited to make the connection between mimesis and sanctification. According to him must the concept of 'following' guide a person in determining the presence of this phenomenon and not the specific word. Van der Watt (2014:2) verifies this statement with his reference to Betz (1967:3) who argues in a similar vein that no philosophical continuity exists between the Greco-Roman and Christian usage of following, but rather a theological continuity. The

\section{The emphasis in italics is by this author.}

19. Hardin (1992:377) got this information from 'The Four Hundred Chapters on Love', written by Maximus, about the spiritual life which he viewed through the 'stereoopticon lens of mimesis and dominion'. 
meaning and usage of this concept moves from the literal level to the conceptual level. In the Gospel of John, this concept (mimesis) figures well within the family metaphor context.

\section{Jesus exhorts his disciples to imitate him}

The imitation of Jesus is described by the author from the perspective of the family metaphor by using the comparative

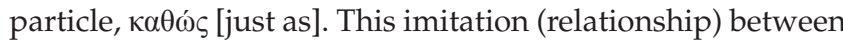
Jesus and his disciples is also explicitly stated in 13:15, where Jesus is depicted as the paradigm for his disciples: 'For I have set you an example (ímó $\delta \varepsilon \imath \mu \alpha)$, that you also should do as I have done to you'.

\section{The new way of life of the disciples is 'just as' (к $\alpha \theta \dot{\omega} \varsigma)$ that of Jesus}

The $\kappa \alpha \theta \omega \varsigma \varsigma$-particle of comparison ('just as') occurs repetitively throughout John in mounting together God-Jesus-disciples in relationships. This particle of comparison $(\kappa \alpha \theta \omega \dot{\varsigma})$ defines the union 'between Father and Son $(5: 30 ; 8: 28 ; 12: 50$; 14:31; 17:2; also cf. 5:17-26), between Jesus and his disciples (13:15, $34 ; 15: 12 ; 17: 14,16)$, and the union involving both relationships (6:57; 10:15; 14:20; 15:9, 10; 17:11, 18, 21, 22; 20:21; cf. 17:23)' (Radl 1991:226; Van der Merwe 2001).

In John, this $\kappa \alpha \theta \omega$ c concept focuses on the following basic aspects: dependence $(5: 19 ; 6: 57 ; 15: 5$; also cf. 12:49; 14:10; $15: 15 ; 17: 8)$, mission $(13: 20 ; 17: 18 ; 20: 21)$, knowledge (10:14, 15), love in obedience (13:34f; 15:9; 15:10; 15:12; 17:23; also cf. $5: 20 ; 14: 12)$, unity $(14: 10 ; 17: 11,21-23$; also cf. 10:30; 14:10f; $14: 20 ; 15: 4)$, glory $(15: 8 ; 17: 1-5 ; 22-24)$ and life $(6: 57)$ (Van der Merwe 2001:139). From this list, John 17:18 is selected as an example to discuss how the $\kappa \alpha \theta \omega$ s-particle of comparison contributes to the understanding of imitating Christ. This is because the 'holiness' theme or concept in John is closely related and connected with the 'mission' concept (see Van der Merwe 2017).

This text asserts that the mission of the disciples is equivalent to the mission of Jesus. According to Lenski (1961[1943]:1149), 'Jesus ... carries the Father's mission to a certain point and then uses the disciples to carry it to completion'. This implies that the 'mission' concept, assigned to Jesus in John, is now reassigned to his disciples. The equivalence lies in the revelatory-salvific activity and is further extended that they also have to become

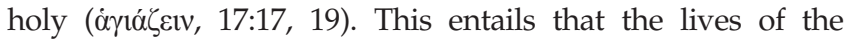
disciples of Jesus have to be transformed and constantly be sanctified concurrently to Jesus' life, to successfully fulfilling the mission of Jesus (Van der Merwe 2002:239-240).

This particle of comparison has been used in John in reference to the daily activities of Jesus and the disciples (dependence, mission, love, obedience and unity). This is a good indication that the en route to holiness relates with how people live every day in life, their conduct in all situations and life with other people.

\section{Jesus the 'example' (úró $\delta \varepsilon เ ү \mu \alpha)$ for his disciples $^{20}$}

The second main part of the gospel of John starts with Jesus on his return to the Father. In Chapter 13, Jesus performs the act of washing the feet of his disciples. After washing their feet (13:4-12), Jesus informs them (13:15) 'For I have given you an example (ínó $\delta \varepsilon \gamma \mu \alpha)$ ' and requests them to do likewise. In most of the theological dictionaries,

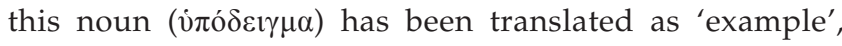
'pattern' or 'model'. ${ }^{21}$ 'Example' refers to demonstrate importance (Onions 1973). 'Pattern' refers to an exemplar deserving imitation (Onions 1973), while 'model' refers to the recommendation for imitation (Onions 1973). From these concise and broad definitions, the noun i $\pi$ ó $\delta \varepsilon 1 \gamma \mu \alpha$ appears to refer to the imitation of both a 'person' or a 'deed'.

Because of the direct linguistic context (Chapter 13) and larger literary context (Chapters 13-17) of the noun

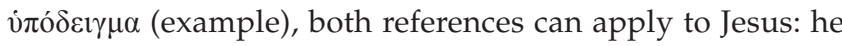
is (in person) an example and sets (in deed) an example. By informing his disciples that, 'For I have set you an example, that you also should do as I have done to you' (13:15), Jesus is communicating to them that they must imitate him as their master who is par excellence the example of sanctification.

This exhortation of Jesus to his disciples implies that they are subjected to this command to follow his example. Even though the noun, vं $\delta^{\delta} \varepsilon \varepsilon \gamma \mu \alpha$ has been interpreted according to the direct context, namely the 'foot washing', it also has more interpretation possibilities (see Schneiders 1999; Van der Merwe 2015a:6-7). The noun vं $\delta^{\delta} \delta \varepsilon \gamma \mu \alpha$ is a composite word. It carries or means more than what it refers to in the immediate context. ${ }^{22}$ With this act, Jesus indicates the purpose of the example. This should be imitated rather than his explanation what the example consists of (Brennema 2014:268).

Jesus, the role model, has set an example for his disciples:

This example is depicted throughout the Fourth Gospel by means of the following related motifs: the light/darkness motif (3:19-21), the shepherd motif (10:2-6, 11-18), the kernel of wheat motif (12:24-26), the foot washing motif (13:2-11; cf. Van der Watt 1992:83), the love motif $(13: 34 ; 15: 12)$, the glorification motif (cf. 17:1-5) and the obedience motif (14:31; 15:10; cf. 14:15, 21, 23, 24; see Van der Merwe 2001; also Schneiders 1999; Van der Watt 1992).

These motifs are all related and therefore reflect related activities in the process of sanctification.

20.For a more thorough discussion of the following two subsections, see Van der Merwe (2001).

21.Danker (2000:1037), Friberg, Friberg and Miller (2000:391), Louw and Nida (1996:253) and Liddell (1996:841) add 'token' and 'mark'.

22.See Brennema (2014:261-274) for a thorough discussion of the 'creative articulation' in mimesis which Aristotle enunciated and the cloning understanding of mimesis as proposed by Plato. 


\section{Towards holiness in John}

Throughout John, as already mentioned, Jesus (the Son) is depicted as imitating God (the Father) within the familia Dei context. In fact, all three, the Father, the Son and the Spirit, are depicted as being holy. In John 17:17, Jesus exhorts (active imperative) the Father to sanctify his followers (disciples) in the truth ${ }^{23}$ for they have to imitate Jesus that enables them to continue his mission. The following aspects that occur implicitly in the synoptic tradition receive special treatment in John, such as: First, any attachment to Jesus is conditional.

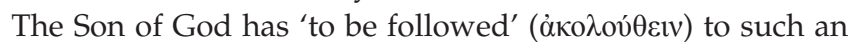
extent of laying down one's own life (10:11; 12:24-26; 13:3638 and 21:15-23). Secondly, this conditionality is further elaborated on by the numerous conditional references referred to as 'unless' ( $\dot{\varepsilon} \alpha \mathbf{\alpha} \nu \mu \eta$ ), throughout the Gospel, and is described from various perspectives. Thirdly, following Jesus is only possible where there is 'faith' ( $\pi 1 \sigma \tau \varepsilon v ́ \varepsilon v)$ that the only true God has sent his Son into the world (17:3, 6-8). Fourthly, the following of Jesus must evolve in 'to abide' ( $\mu \varepsilon \varepsilon v \varepsilon v$ ) in Jesus and Jesus abiding in the disciples. He decisively said, 'Those who abide in me and I in them bear much fruit, because apart from me you can do nothing' $(15: 4,5)$. Lastly, his disciples have 'to obey' ( which 'to love one another' is the most important one (15:12, 17; cf. 14:23, 24, 28).

\section{Jesus calls his disciples 'to follow me'

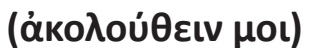

The call by Jesus to follow him ( $\dot{\alpha} \kappa o \lambda$ ov́ $\theta \varepsilon v v \mu o 1)$ occurs as a refrain throughout John: 1:35-43; 8:12; 10:4, 5, 27; 12:26; 13:36-38; 21:19-23. The call to follow him is theologically a God-ward movement. Practically, it implies to be with Jesus where he is (1:39), being to be led by Jesus and doing what Jesus commands to do (Kim 2016:225). This invitation of Jesus to follow him was not only a single invitation, but occurs repetitively throughout John. It was not only to accompanying him physically. The motif behind Jesus' calling was to have permanent fellowship with him (Kim 2016:226). ${ }^{24}$ This is exactly what sanctification is.

When Jesus refers to himself to be the light of the world (8:12) and calls everyone to come to the light of life, he urges them to 'follow' the light. In 10:4, Jesus points out that the sheep follow the guidance of the shepherd because they know his voice. Following Jesus comprises to being led by Jesus' guidance. In 12:26, Jesus relates following him with 'to serve'

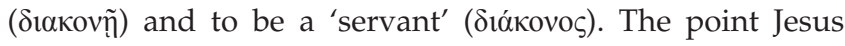
wants to make here is that following him entails to serve him as his servants (Kim 2016:226). Jesus himself is portrayed as the perfect servant of God, accomplishing all things God commands him to do $(5: 36 ; 10: 18 ; 14: 31 ; 15: 10 ; 17: 4)$ and to

23.The conceptual link of these aspects mentioned and discussed in the 'en route' to holiness is thoroughly discussed and verified in another article (Van der Merwe 2017).

24.The first reference to follow Jesus (1:37-51) is catechetical: (1) the disciples refer to Jesus with titles to acknowledge his honor and (2) Jesus reveals himself significantly to them. The titles ascribed to Jesus ('Lamb of God', 'Messiah', 'the one of whom Moses and the prophets wrote', 'Son of God and King of Israel') are dense and of progressive significance. For 'Neyrey (2007:56), this illustrates a developing progressive significance. For Neyrey (2007:5
appreciation of the role and status of Jesus. live according to the will of the one who has sent him $(4: 34 ; 5: 30 ; 6: 38 ; 8: 29)$.

In 12:26, John also adds a new perspective to coach the reader how such service is possible. The en route in following Jesus involves first to die in oneself. The death of self-interest (cf. 12:24 and also 21:15-23) is required. Jesus challenges his disciples, 'Whoever serves me must follow me ...' and links it with a promise 'and where I am, there will my servant be also' (Köstenberger 1998:178). Following Jesus (the en route of holiness) then involves 'following him unto his death' (cf. 12:24). This involves a lifestyle of self-sacrifice (cf. 13:1-15; 15:13). Jesus himself has modelled this way of life: he is 'the

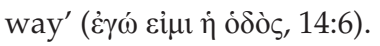

The verb $\dot{\alpha} \kappa \circ \lambda$ ov $\theta \varepsilon v$ [to follow] occurs for the last time in 21:18-19. Also here, John stresses that to follow Jesus means to partake in his death as he glorified God through his death (12:33; 17:1-5; 18:32; cf. 13:31-32). In the final pericope (21:2025) of the Gospel, Peter and the Beloved Disciple became prototypes that there are different ways of following the crucified and resurrected Christ. Thus, following Jesus can also entail physical death as what happened to Peter and still today where many Christians are assassinated because of their faith in Christ (cf. Köstenberger 1998:180).

Those who follow Jesus to the end will be awarded to be where he is. Their holiness will enable them to see his glory (17:24, cf. Kim 2016:227). Consequently, the lived experience embedded in the following of Jesus and being with him 'includes both going down with Jesus to the cross and going up with him to the presence of the "holy" Father. Both humility and honour, both death and glory will prevail' (cf. Kim 2016:227).

The brief investigation of these texts about 'to follow me'

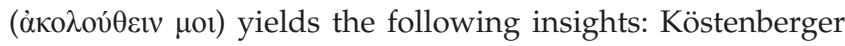
(1998:178) points out that there is a movement, away from literal following to a figurative following (cf. 1:37, 40, 43 and 8:12; also $13: 13-38$ ) of Jesus. ${ }^{25}$ In 1:35-51, the initial opening call narrative, the invitation by Jesus of two disciples of the Baptist to follow him was meant to follow Jesus literally and physically. The figurative following of Jesus occurs later in the second invitation to follow him (8:12). Here, reference is made that the one following Jesus will not 'walk in darkness', but have the 'light of life'. Even in 13:36-38, the literal

25.The first and third meanings from Danker (2000:36) are: "1. to move behind someone in the same direction, come after... 3. w. transition to the fig[urative]
$\mathrm{m}[$ ea $] \mathrm{n}[\mathrm{in}] \mathrm{g}$. to follow someone as a disciple, be a disciple, follow'. Wead (1970:115) $\mathrm{m}[\mathrm{ea}] \mathrm{n}[\mathrm{in}] \mathrm{g}$. to follow someone as a disciple, be a disciple, follow'. Wead (1970:115)
agrees with this change and movement. According to him, John uses in this passage the primary meaning of the words as an illustration of the secondary meaning which he intends as more important. The primary meaning of the text pictures a man walking behind or with Christ. This man walks with assurance, for he does not walk where he cannot see. The secondary meaning shows this man who has given himself to Christ as his disciple walking in the patterns of behaviour set by the Christ with the light of this example. Richard (1985:100) points out that in the second last pericope (1:35-42), the emphasis is upon the actual event, for 'Jesus turns and sees the men following him'. Their action of following Jesus is firmly intended. Yet, John is not content to leave it there. In 1:40, Andrew, one of those who followed him is not content to leave it there. In 1:40, Andrew, one of those who followed him

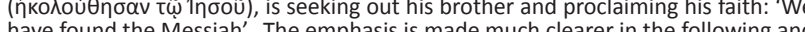
have found the Messiah'. The emphasis is made much clearer in the following and last pericope in Chapter 1. Here, Jesus calls Philip imperatively, 'follow me'

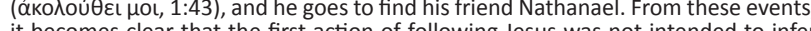
it becomes clear that the first action of following Jesus was not intended to infer that the disciples merely followed him, but that they also came to a decision that made them followers. Both elements are actively present. 
meaning and figurative meaning with spiritual overtones of 'follow' are used side by side (Köstenberger 1998:178). ${ }^{26}$

Wead (1970:115) adds another perspective to the understanding of these texts and compliment the interpretation of Köstenberger. According to him, John uses in 8:12 the primary meaning of the words. This is an illustration of the secondary meaning which he intends as more important. He explains it as follows: the primary meaning of the text pictures a man walking behind or with Christ. The secondary meaning of the text comprises this person who has devoted himself to Christ, as his disciple walks according to the patterns of behaviour set by the Christ in light of this example. Both meanings complement each other; they are not complete without the other (Wead 1970:115; cf. also Brennema 2014 on mimesis).

\section{The conditional (દ่àv $\mu \eta ́)$ expressions in John}

The petition for discipleship and sanctification begins with 'Unless ...'. These Greek phrases ('̇̀̀ $\mu$ í) refer to many rites of transformation articulated in John. ${ }^{27}$ Eight fundamental

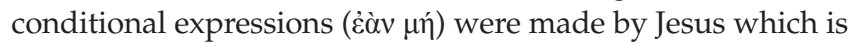
vis-à-vis a typical Johannine idiolect (cf. Thate 2007:562). ${ }^{28}$ Thate (2007:562), in his article on Conditionality in John's Gospel: ..., defines conditional sentences in reference to the definition by Funk. For Funk, a conditional sentence consists 'of a subordinate clause stating the condition or supposition (the if clause) and a main clause giving the inference or conclusion' (Funk 1973:679). He also quotes Wallace (1996:681) who states that conditional sentences can be 'uttered as a veiled threat, request, command, and the like' (Thate 2007:572).

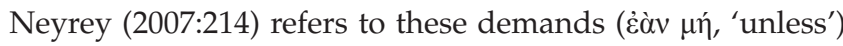
as demands whereby an insider becomes transformed into an exclusive group by virtue of critical imitation of Jesus. These exhortations by Jesus argue for the 'advantage ${ }^{29}$ of his disciples to share with him (in his holiness). Such sharing is, in fact, the aim of deliberative rhetoric. First, it is evident that throughout the Gospel, it is clearly the intention of Jesus to instruct (and discourage) his disciples regarding particular ways of conduct. Secondly, deliberative rhetoric is typically future oriented. ${ }^{30}$ Only sometimes, it is present. ${ }^{31}$ Johannine scholars agree that the time reference in John is predominantly

26 .In these texts, there is also a broadening of the following of Jesus. The focus has changed from the 'following' of the initial disciples of Jesus (1:37-43) to the 'following' of every believer (cf. 8:12; Chapter 10 and 12:26).

27.See $3: 3,5 ; 6: 53 ; 8: 24 ; 12: 24 ; 13: 8 ; 15: 4,6$; also $3: 27 ; 4: 48 ; 8: 51,52 ; 12: 47$. The two 'unless' (غ́àv $\mu$ ') ) statements in $6: 44,65$ relate to the Father ('no one can come to me unless it is granted by the Father').

28.Confer Thate (2007:564-571) for a thorough analysis and discussion on Johannine conditionals.

29.See deliberative rhetoric of Aristotle. 'The definition of virtue, with which the topic of praise is most closely connected' (Aristotle, Rhetoric 15 1362a).

30.According to Aristotle, 'Further, to each of these a special time is appropriate: to the deliberative the future' (Aristotle, Rhetoric 13 1358b 4, 14 ; also 1359a 1-2, 2 18; 1392a 5). According to Quintilian: 'We praise or denounce past actions, we deliberate about the future' (Quintilian 347,386 ).

31.'It is evident, then, what things, likely to happen or already existing, the orator should aim at, when exhorting, and what when dissuading: for they are opposites. sut since aim at, when exhorting, and what when dissuading, for they are opposites. But since the aim before the deliberative oratoris that which is expedient, and men deliberate, not about the end (Aristotle, Rhetoric 161362 a 1, "whether future or present, should be the aim of those who recommend a certain course ...' (Aristotle, Rhetoric 18 1366a 7) present. However, it is clear that the course of action advised by Jesus is to be performed immediately or to be continued if (cf. Watson 1988:59; also Neyrey 2007:214) it has already being employed. ${ }^{32}$

Below, there is a list of the conditional expressions in John. The first two $(3: 3,5)$ conditional expressions are general expressions about born again and are connected with the Kingdom of God. In 1:12-13, rebirth is connected to Jesus. All the other conditional expressions relate the believer directly with Jesus:

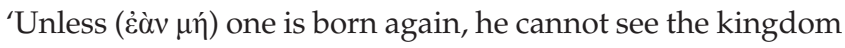
of God'. (3:3)

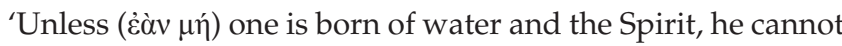
enter the kingdom of God'. (3:5)

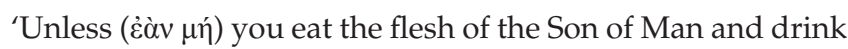
his blood, you have no life in you'. (6:53)

'Unless (

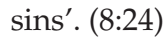

'Unless ( $(\dot{\alpha} \alpha \nu \mu \eta ́)$ a grain of wheat falls into the earth and dies'. (12:24f)

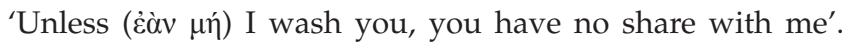
$(13: 8)$

'As the branch cannot bear fruit by itself, unless ( abides in the vine, neither can you,

unless ( $(\dot{\alpha} \alpha \nu \mu \eta ́)$ you abide in me'. (15:4)

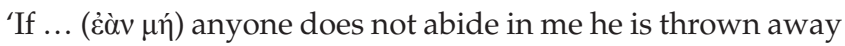
like a branch and withers'. (15:6)

Neyrey (2007:215) points out that this deliberative rhetoric

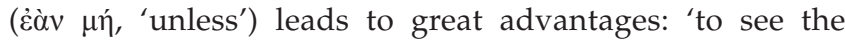
kingdom of God' (3:3), 'will not die in sin' (8:24), 'will share in the benefits of the death of Jesus' (13:8) and 'will bear much fruit' (15:4; also cf. Newman and Nida 1993:432). The culmination of all this will be the glorification of 'God' $(17: 1,4)$, 'Jesus' $(17: 1,5,10)$ and the 'disciples' (17:22).

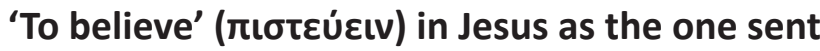 by the Father into the world}

John presents two kinds of faith to the reader. The first kind consists of a:

personal involvement with and allegiance to Jesus entailing trust and intimacy. The second is an understanding of faith as acceptance of a creed or at least of creedal assertions about Christ. ${ }^{33}$ (Kysar 2007:110)

32.It should also describe a future activity: As is typical of deliberative rhetoric, the stasis of the rhetoric which underlies the question is the stasis of quality. The nature of a thing is the primary concern, for the focus is upon the characteristics of a life worthy of the gospel. (cf. Watson 1988:60)

33.See Hebrews 11; James 2:17; 1 John 5:1; 3 John 3-11; Jude 3 
Both are important for the en route to holiness. Firstly to be connected with Christ; secondly to be distinguished from the 'world'. The first kind of faith concerns a personal dimension and necessitates the entire being of the person to be connected with Christ. The second kind of faith identifies these believers when they affirm that Jesus is the Christ. This confession distinguishes the believers in the Johannine community from the world around them (Kysar 2007:110).

For John, 'to believe' is always an active matter. Faith is not a state of being or something the believer owns. Faith is something the believer does and keep on doing; it is a dynamic becoming of what the believer is called to be. If John always using the verb, then believing is a decision made once, only to be repeated over and over again (Kysar 2007:111).

This faith in Jesus has a specific content. In 6:29, Jesus makes the statement, 'This is the work of God, that you believe in him whom He has sent'. Then, in the following, two faith centred phrases, Jesus expresses the same thought. John $11: 42^{34}$ and $17: 8^{35}$ are nearly verbatim the same. In the first text (11:42), the verb $\pi 1 \sigma \tau \varepsilon v i \varepsilon v$ [to believe] is used in the aorist subjunctive mode to express a wish, while that wish has been fulfilled in the second text (17:8), aorist indicative. Both these expressions of Jesus occur in him praying to the Father. With the phrases 'whom He has sent' and 'that you sent me', it qualifies Jesus not only as sent by the Father, but also identifies Jesus.

Prior to the miracle to raise Lazarus from death, Jesus' prayer is that he wishes (subjunctive) the people will believe that the Father sent him (11:42). Jesus is not concerned to demonstrate to the people his miracle abilities, but rather to reveal through this miracle the active power of God in him. This is verified in the pronoun you (in the phrase you sent me) which is emphatically used here (Newman \& Nida 1993:376). People must be assured that this is divine work (Calvin \& Pringle 2010:446). The Father has sent the Son to perform the Father's work on the earth. Such faith unites the believer with 'the holy one of God' where the believer's sanctification process starts.

\section{Jesus calls on his disciples 'to abide in me' ( $\mu \varepsilon \dot{v \varepsilon เ v ~ \varepsilon ̇ v ~ \varepsilon ̇ \mu o i ́) ~}$}

The abiding motif is another prominent theme in John. In Chapter 15, the intensity of this expression is more intense. The verb $\mu$ śveıv [to abide] occurs 29 times in John of which seven occurs in Chapter 15. This high-frequency constitutes emphasis and clarity. ${ }^{36}$ The nature of 'abide' is more advanced here because of its connection with the vine image (Ridderbos 1997:517). Therefore, of relevance for this research is Chapter

34.11:42 'I knew that you always hear me, but I have said this for the sake of the

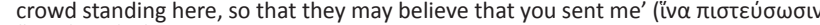

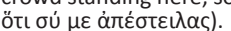

$35.17: 8^{\prime} \ldots$ for the words that you gave to me I have given to them, and they have received them and know in truth that I came from you; and they have believed that

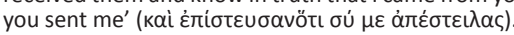

$36.1: 33,38,39 ; 3: 36 ; 4: 27 ; 5: 38 ; 6: 27,56 ; 7: 13 ; 8: 35(2 \times) ; 9: 41 ; 12: 24,34,42 ; 14: 10$, 17,$25 ; 15: 4(2 \times), 5,6,10(2 \times), 16 ; 20: 5 ; 21: 4,22,23$
15:4-5 where the believer is called to abide in Jesus and Jesus in the believer, for the believer to bear much fruit. ${ }^{37}$ This subsection focusses on the human side of the indwelling. 'Abiding in Jesus' is not a condition of existence, but what Jesus' disciples have already received in following Jesus. It is rather an adherence to him as the vital source to bear much fruit (Ridderbos 1997:517).

In 15:5, Jesus taught his disciples the following: 'I am the vine, you are the branches. Those who abide in me and I in them bear much fruit, because apart from me you can do nothing'. The meaning of this statement is obvious: to 'abide' in Christ is to become fruitful, ${ }^{38}$ nonetheless 'without me you can do nothing' (15:5). Bultmann (1971:538) says, 'Alongside the promise stands the threat: whoever is not loyal will be destroyed'. The destruction comprises the vine being separated from the stem that provides life. Once more John emphasises the worthlessness of 'not abiding in Jesus', 'Whoever does not abide in me is thrown away like a branch and withers' (15:6). Prolific fellowship with Jesus is only viable when the fruit is pruned. Unpruned fruit cannot bear (much) fruit (Bultmann 1971:538). Thus, apart from Christ, 'no fruit can be produced' or 'no holiness can be achieved'. In Christ, 'much fruit can be produced' or 'holiness can be achieved'. Beasley-Murray (2002:273), incisively, points out that this statement by Jesus echoes his personal dependence on his Father. Without the Father, he seems to be helpless $(5: 19,30)$.

This conditional expression is critically important and refers to the crucial statement in the protasis of 15:4, 'Abide in me as I abide in you'. Jesus' abidance is constituted through obedience to his word and the Spirit who makes him present. Without this mutual abiding, they in him and he in them, they will not bear any fruit (Ridderbos 1997:517). The participial reference ó $\mu \varepsilon \dot{v} \omega v$ [whoever abides] may be regarded as conditional, for the 'bearing of much fruit' which is part of the en route to holiness. According to Newman and Nida (1993:482), this understanding can mean that '... he will be able to accomplish much' fruit. To abide in Jesus is according to this text (15:4-17) to keep his commandments and words.

Those who dwell in Jesus came to be known as his disciples as an indication of their new identity in Jesus. The mutual indwelling caused a severe transformation. This activity 'to abide' ( $\mu \varepsilon \dot{v \varepsilon} v$ ) consequently became essential for sanctification. Over a period of time, Jesus' followers matured into a new community of friendship love. In this context, 'to abide' is directly linked to the words and love of Jesus. For the disciples to maintaining, the reciprocal relationship is from them required to dwelling ( $\mu \varepsilon \varepsilon v \varepsilon v v$ ) in the words of Jesus. Jesus' words had a cleansing effect on them (15:4) and therefore should continually dwell in them (15:7). When the

37.John 15:4-5:Abide in me as I abide in you. Just as the branch cannot bear fruit by itself unless it abides in the vine, neither can you unless you abide in me ${ }^{5} \mathrm{l}$ am the vine, you are the branches. Those who abide in me and I in them bear much fruit, because apart from me you can do nothing.

38.Fruit bearing signifies, according to Bultmann (1971): 'every demonstration of vitality of faith, to which, according to $v v 9-17$, reciprocal love above all belongs' we may add, in the light of 15:16, 'to which also effective mission in bringing to Christ men and women in repentance and faith belongs' (pp. 532-533) 
believers dwell in the love of Jesus (15:9), it brings about long-term transformation of the community's way of life. The foundation of their conduct must resonate with the new love commandment of Jesus (Jn 13:34; 15:12-17; Stander 2017:166).

This resulted in joy which seems to be a pivotal motif in John, especially in both John 15:11 and 17:13. This joy characterises those believers who experience a dynamic intimate relationship with God in Christ. Complete inner joy reflects the presence of God in Jesus who mediated the presence of the divine among people. A joyful life in which God is glorified contributes to devote oneself to continue the divine-human indwelling. 'Indwelling of God', 'unity', 'bearing of fruit' and 'joy' are closely related. The mutuality in John 15 characterises the mystical union between God and the followers of Jesus. Consequently, unity with the divine and sanctification turned out to be essential features of a transformed life through mutual indwelling (Stander 2017:166).

John notes a number of times about Jesus' intimate relationship with people and the effect of this on their lives. This is evident from: his guidance of his first disciples who quit following the Baptist to follow him (1:35-51), his conversation with Nathanael the man of little faith, Nicodemus a Pharisee and member of the Sanhedrin (3:1-21), the Samaritan woman who became a disciple and witness about him (4:1-42), the self-assured and outspoken Simon Peter (6:68-69; 13:36-38), the doubting Thomas Didimus (20:24-29) and finally, the disciple whom Jesus loved (19:25-27, entire Gospel). These people range from different spheres of society. This illustrates how the power of Jesus overwhelms seekers and inquirers. His unselfish love, humility and guidance influenced them to become part of a new community of truth, love and holiness (cf. Stander 2017:167).

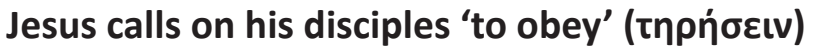 his commandments}

In John, the Christian life revolves around divine love. Therefore, responsive love for Christ finds expression in the obedient actions of his followers. The phrase 'If you love me, you will keep my commandments' (14:15; cf. 14:21) ${ }^{39}$ relates closely to 'Those who love me will keep my word' (14:23) and occurs frequently in Chapters 14 and 15 and forms a parallelism:

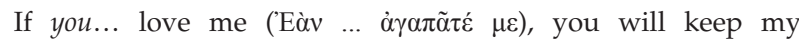
commandments. (14:15)

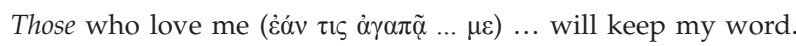
$(14: 23)$

From this parallelism, the following four deductions can be made:

1. The phrases 'my commandments' and 'my word' are semantically similar and refer to the revelation of God in and through Jesus.

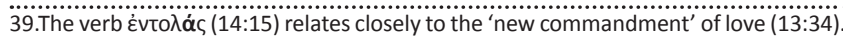

2. The phrases 'love me' indicate a relationship between Jesus and the disciples.

3. These two phrases are two typical conditional sentences

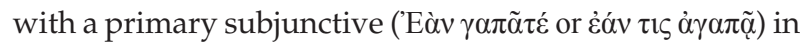
the protasis and a future indicative ( in the apodosis. John uses these conditional sentences to picture, in particular, a future condition (will keep my word or commandments) which will be practical and will be the product of a relationship (love me) that has been initiated (or is going to take place) (Abbot \& Mansfield 1973:47). At this point, Jesus sets an example: 'I do as the Father has commanded me' (14:31). His true relationship with God implies as a result of obedience to God's

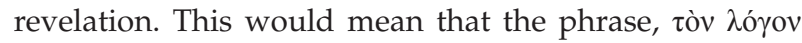

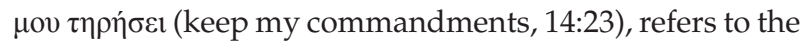
result of their relationship.

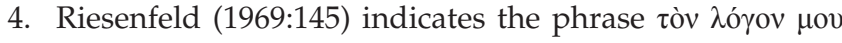

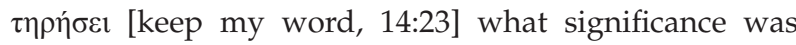
rendered to the communicated message.

5. All this boils down to the point that the love of the Son and that of the disciples ought to be equivalent to the love of the Father. We find here that the same obedience which Jesus reveals on the Father's commandments he now also expects from his disciples. The love of the disciples of Jesus must therefore in no way differ from the love of Jesus, because the nature of this love is determined by the love of God. This implies that the love of the disciples is merely an expression of the love of God and their deeds must compare with those of Jesus in a particular situation (Van der Merwe 1995:448; Van der Watt 1992:83). This characterises sanctification.

Obedience to the commandments or word of Jesus is, semantically spoken, obedience to the will of 'Him who sent me' for Jesus endeavoured to live according to the will of 'Him who sent me' $(4: 34 ; 5: 30 ; 6: 38 ; 8: 29) .{ }^{40}$ This should be the consequence of the love of the disciples for their master $(14: 15,21,23)$. Jesus emphasises this point in 15:9-10 (Van der Merwe 1995:453). Jesus uses here his obedience to the commandments of the Father as an example, rather as a

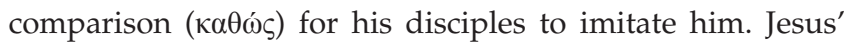
behaviour is in particular the manifestation of the will of the Father $(4: 34 ; 6: 38) .{ }^{41}$

Van der Watt (1992:86) correctly indicates that during his ministry when Jesus was obedient to the will of the Father, the will of the Father has then became his will and his will consequently became the same as the will of the Father. If this argument is true, then it implies that the commands of Jesus to his disciples relate to the will of God for him, Jesus. Then, the will of the Father for them will be similar as the will of the Father for Jesus (Van der Merwe 1995:454).

40. Quite interesting is that in all four these texts, Jesus does not refer to the will of God or the Father but the 'will of him who sent me'. Then, in the immediate literary contexts of 5:30; $6: 38$ and 8:29, he combines the 'him who sent me' with the 'Father'.

41.Only once he refers to the will of God in reference to his audience, 'Anyone who resolves to do the will of God will know whether the teaching is from God or whether I am speaking on my own' (Jn 7:17). 
An evaluation of Jesus' command to his disciples (15:9-10) indicates that obedience evolves out of love and love out of obedience (cf. Barrett 1978:476).

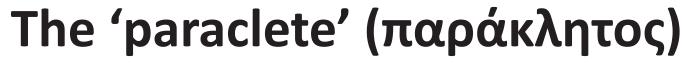 continues to sanctify Jesus' disciples}

The imitation of Jesus is implicitly stated in the assertions of the indwelling of Christ in his disciples through the presence of the Paraclete ( $\pi \alpha \rho \alpha \dot{\kappa} \lambda \eta \tau o \varsigma)$. Jesus will carry on to fulfil his mission via his disciples. John wants to emphasise (three paraclete references, $14: 16-17 ; 15: 26 ; 16: 7-14$; also cf. 17:26) that the risen Jesus is not absent at all from the world. In 17:26, he says, 'I made known to them your name, and I will continue to make it known, that the love with which you have loved me may be in them, and I in them'. According to John, Jesus is present and lives in the community and among his followers (17:26). The Spirit makes this Jesus known and experiential (cf. Koester 2008:147, 149, 150). Directly after Jesus has spoken about the Paraclete who will dwell with his disciples and will be in them, he refers that he and the Father will come to make their dwelling place among those who love him and is obedient to his word (14:23; cf. Koester 2008:151). This implies that they will continue and duplicate the mission of Jesus who sends them, to continue the divine mission of the Son. The en route to holiness is also the en route into the world to continue and to fulfil the mission of the Father or Son (Van der Merwe 2002).

An important feature of sanctification is the bearing of fruit as referred to in (15:8). This happens through witnessing on behalf of Jesus (15:5). Despite the hatred coming from the world, the followers of Jesus are called to witnessing under the guidance and assistance of the Paraclete. Any form of hardship recalls the reference to pruning (Jn 15:2) as part of the ongoing transformation and sanctification of the disciples. Therefore, Jesus encourages his disciples to persevere and to stay strong in their faith, constituted through mutual indwelling. The vital choice of following Jesus and of dwelling in him establishes moving on a spiritual journey of sanctification. Finally, indwelling in Christ and the guidance of the Spirit will bring forth to fruition, the sanctification in daily life through commitment and perseverance (cf. Stander 2017:167).

\section{Conclusion}

In the Gospel of John, the Father, the Son and the Spirit have been identified by the author as being holy (ö $110 \varsigma)$. The disciples of Jesus are also explicitly called to be sanctified

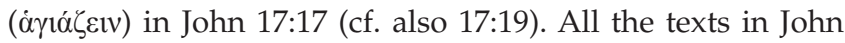

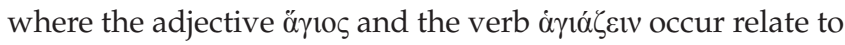
the mission of the Son and in 17:17 to the continuation of Jesus' mission by his disciples. The disciples are called to become like Jesus (sanctify, 17:17, 19) to continue his (God's) mission. According to John, quite a number of semantic related references, used by the author to exhort the disciples to follow Jesus, relate to mimicry.
This article started with a concise picturing of Jesus in John for he is the 'holy one of God' and one to be imitated. The second section discusses briefly the meaning and understanding of mimesis in order to make sense of the mimicry of Jesus referred to throughout John. Bearing in mind of what Plato, Aristotle and Ricoeur wrote about mimesis, it is clear that John presented Jesus in such a way that his character should be mirrored (according to Plato's view) in the lives of his disciples. The audience of the Gospel would also know that for mimetic representation, a new creative understanding and insight into the subject matter would be required to imitate Jesus in a different time (according to Aristotle's view). In order to achieve this, a contemporary comprehensive hermeneutical approach (according to Ricoeur's view) is needed that involves both the understanding of the original text (act and principles) and a newly creative mimetic act resonating with the articulation of the discernment.

The next two sections discussed those features in John that constitute the en route to and character of holiness. From the discussion, it became evident that they are all linked with Jesus, in order to exhort his followers to follow Jesus, to relate with him, to become in a sense like Jesus and to continue his mission (17:18; 20:21; cf. also 1 Jn 2:6). This is especially evident from the numerous $\kappa \alpha \theta \omega \dot{c}$-formulas and the exhortation of Jesus to follow his example (13:15), and finally that he will remain in their presence through the Paraclete to assist them en route to holiness.

The aspects pointed out and discussed clearly illustrated that according to John, the en route to holiness is to live a life as close as possible to the life of Jesus who revealed ( $\dot{\varepsilon} \xi \eta \gamma \varepsilon \tilde{\varepsilon} \sigma \theta \alpha$, 1:18) God ('holy Father', 17:11) in this world. In continuing, this mission of Jesus God will then be revealed through the lives of Jesus' disciples. Through them, the divine will be experienced, heard, seen and be glorified. The contribution of this research lies not only in providing a holistic overview of sanctification in John, but also in connecting the en route to and character of holiness in John with the character of Jesus which revolves around his mission of revelation and salvation.

\section{Acknowledgements Competing interests}

The author declares that he has no financial or personal relationships which may have inappropriately influenced him in writing this article.

\section{References}

Abbot, E. \& Mansfield, E.D., 1973, A primer of Greek grammar, Rivingstons, London. Aristotle, 330-350 B.C.E., Poetics, transl. S.H. Butcher, viewed 01 February 2017, from http://classics.mit.edu/Aristotle/poetics.1.1.htm/

Aristotle, 350 B.C.E., Nicomachean ethics, transl. W.D. Ross, viewed 01 February 2017 from http://classics.mit.edu/Aristotle/nicomachaen.html

Aristotle, 350 B.C.E., Rhetoric, viewed 19 February 2015, from http://www.perseus tufts.edu/hopper/text?doc $=$ Perseus ${ }^{\mathrm{A}}$ text $\% 3^{\mathrm{A}} 1999.01 .0060 \% 3 \mathrm{Abekker}+$ page $\%$ 3D1362a

Aristotle, 1944, Politics, transl. H. Rackham, Harvard University Press, London, viewed 01 March 2017, from http://www. perseus.tufts.edu/hopper/text?doc=Perseus\% 3Atext\%3A1999.01.0058\%3Abook\%3D7\%3Asection\%3D1336b 
Barrett, C.K., 1978, The Gospel according to St John, SPCK, London.

Beasley-Murray, G.R., 2002, John, Word, Incorporated, Dallas, TX.

Betz, H.D., 1967, Nachfolge und Nachahmung Jesu Christi im Neuen Testament, Mohr \& Siebeck, Tübingen.

Brennema, C., 2014, 'Mimesis in John 13. Cloning or creative articulation?', Novum Testamentum 56, 261-274. https://doi.org/10.1163/15685365-12341465

Bultmann, R., 1971, The Gospel of John, transl. B. Blackwell, Basil, Oxford.

Calvin, J. \& Pringle, W., 2010, Commentary on the Gospel according to John, Logos Bible Software, Bellingham.

Castelli, E.A., 1991, Imitating Paul: A discourse of power, Westminster John Knox Louisville, viewed 30 July 2017, from https://books.google.co.za/books?id=e1KFQ aZR3kMC\&printsec=frontcover\&dq=Castelli,+E.A., $+1991,+$ Imitating+Paul:+A+disc

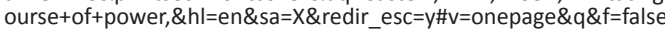

Culpepper, R.A., 1991, 'The Johannine Hypodeigma. A Reading of John 13', Semeia 53, 141-144.

Danker, F.W. (ed.), 2000, Greek-English lexicon of the New Testament and other early Christian literature, 3rd edn., University of Chicago Press, Chicago, IL. (W. Bauer F.W. Danker, W.F. Arndt and F.W. Gingrich, BDAG).

Friberg, T., Friberg, B. \& Miller, N.F., 2000, Analytical lexicon of the Greek New Testament, Trafford Publishing, Bloomington.

Funk, R.W., 1973, A beginning-intermediate Grammar of Hellenistic Greek (Vol II: Syntax), Society of Biblical Literature, Missoula, MT.

Hardin, M., 1992, 'Mimesis and dominion the dynamics of violence and the imitation of Christ in Maximus confessor', St Vladimir's Theological Quarterly 36(4), 373385.

Harrison, J.R., 2013, 'The imitation of the "great man" in antiquity: Paul's inversion of a cultural icon', in S.E. Porter \& A.W. Pitts (eds.), Christian origins and GrecoRoman culture, pp. 213-254, Brill, Leiden.

Kim, S., 2016, The spirituality of following Jesus according to the Gospel of John: An

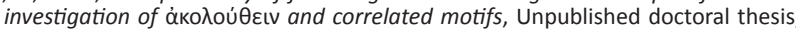
University of South Africa, Pretoria.

Koester, C.R., 2008, The word of life: A theology of John's gospel, Eerdmans Publishing Company, Grand Rapids, MI.

Köstenberger, A.J., 1998, The missions of Jesus \& the disciples according to the Fourth Gospel, Eerdmans Publishing Company, Grand Rapids, MI.

Köstenberger, A.J., 2004, John, Baker Academic, Grand Rapids, MI.

Kysar, R., 2007, John the Maverick Gospel, Westminster John Knox Press, Louisville, KY. Lenski, R.C.H., 1961 [1943], The interpretation of St John's Gospel, Provo, Utah.

Liddell, H.G., 1996, A lexicon: Abridged from Liddell and Scott's Greek-English lexicon, Logos Research Systems, Inc., Oak Harbor.

Louw, J.P. \& Nida, E.A., 1996, Greek-English lexicon of the New Testament: Based on semantic domains, vol. I, United Bible Societies, New York.

Mack, B.L., 1995, Who wrote the New Testament? The making of the Christian myth, Harper Collins, New York.

Miriam Webster Dictionary, 2017, Mimesis, viewed 01 March 2017, from https:// www.merriam-webster.com/ dictionary/mimesis

Newman, B.M. \& Nida, E.A., 1993, A handbook on the Gospel of John, United Bible Societies, New York.

Neyrey, J.H., 2007, The Gospel of John, Cambridge University Press, Cambridge.

Nightingale, A., 2006, 'Mimesis: Ancient Greek literary theory', in P. Waugh (ed.), Literary theory and criticism: An Oxford guide, pp. 37-47, Oxford University Press, Oxford.

Parris, D.P., 2002, 'Imitating the parables: Allegory, narrative and the role of mimesis', Journal of the Society of the New Testament 25(1), 33-53. https://doi. org/10.1177/0142064X0202500102

Plato, 360 B.C.E., The Republic Book III, transl. B. Jowett, viewed 18 April 2017, from http://classics.mit.edu/Plato/republic.4.iii.html
Plato, Republic, Plato in twelve volumes, English translation, The Perseus Catalogue, viewed 10 March 2017, from http://www. perseus.tufts.edu/hopper/text?doc=Pe rseus\%3Atext\%3A1999.01.0168\%3A book\%3D3\%3Asection\%3D393c

Quintilian, 1920, Institutio Oratoria (Book III, chap. 1-5), Loeb Classical Library edition, viewed 10 March 2017, from http://penelope.uchicago.edu/Thayer/E/Roman/ Texts/Quintilian/InstitutioOratoria / $3 A^{*}$.html

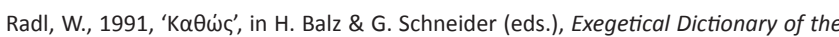
New Testament, vol. II, pp. 226-228, Eerdmans Publishing Company, Grand Rapids, MI.

Richard, E., 1985, 'Expressions of double meaning and their function in the Gospel of 'John', New Testament Studies 31, 96-112. https://doi.org/10.1017/S00 28688500012947

Ricoeur, P., 1990 [1983], Time and narrative, vol. I, transl. C. McLaughlin \& D. Pellauer, The University of Chicago Press, Chicago, IL.

Ridderbos, H., 1997, The Gospel of John: A theological commentary, Eerdmans Publishing Company, Grand Rapids, MI.

Riesenfeld, H., 1969, 'Tnpeĩv', in G. Friedrich (ed.), Theological Dictionary of the New Testament, vol. VIII, pp. 141-145, Kohl Hammer, Stuttgart.

Schnackenburg, R., 1980, The Gospel according to St John, vol. II, Burns \& Oates, London.

Schneiders, S.M., 1999, Written that you may believe. Encountering Jesus in the Fourth Gospel, Crossroad, New York.

Onions, C.T. (ed.), 1973, Shorter Oxford English Dictionary, Caledon Press, Oxford.

Sörbom, G., 2002, 'The classic concept of mimesis', in P. Smith \& C. Wilde (eds.), A companion to art theory, pp. 19-28, Blackwell, Oxford.

Stander, A.J.J., 2017, 'Menein as key to a mystical reading of John 15 ', Unpublished doctoral thesis, University of the Free State, Bloemfontein.

Thate, M.J., 2007, 'Conditionality in John's Gospel: A critique and examination of time and reality as classically conceived in conditional constructions', Journal of the Evangelical Theological Society 50(3), 561-572.

Van der Merwe, D.G., 1995, 'Discipleship in the fourth Gospel', Unpublished doctoral thesis, University of Pretoria, Pretoria.

Van der Merwe, D.G., 2001, 'Imitatio Christi in the fourth gospel', Verbum et Ecclesia 22(1), 131-148.

Van der Merwe, D.G., 2002, 'The character of unity expected among the disciples of Jesus, according to John 17:20-23', Acta Patristica et Byzantina 13, 224-254.

Van der Merwe, D.G., 2013, 'Old Testament spirituality in the Gospel of John', Verbum et Ecclesia 35(1), 1-9.

Van der Merwe, D.G., 2015a, 'Wim J.C. Weren, studies in Matthew's Gospel: Literary design, intertextuality, and social setting', HTS Theological Studies 71(3), 1-8. https://doi.org/10.4102/ve.v22i1.628

Van der Merwe, D.G., 2015b, 'Reading the bible in the 21st century; some hermeneutical principles' Part 1, Verbum et Ecclesia 36(1), 1-8.

Van der Merwe, D.G., 2015c, 'Reading the bible in the 21st century; some hermeneutical principles' Part 2, Verbum et Ecclesia 36(1), 1-8

Van der Merwe, D.G., 2017, 'Conceptualising holiness in the Gospel of John: The mode and objectives of holiness (part 1)', HTS Theological Studies 73(3), 1-9. https:// doi.org/10.4102/hts.v73i3.3421

Van der Watt, J.G., 1992, 'Julle moet mekaar liefhe: Etiek in die Johannesevangelie', Scriptura S9A, 7, 4-96.

Van der Watt, J.G., 2014, 'Navolging van Jesus, mimesis en 1 Johannes', In die Skriflig 48(1), 1-9.

Wallace, D.B., 1996, Greek grammar beyond the basics: An exegetical syntax of the New Testament, Zondervan, Grand Rapids, MI.

Watson, D.F., 1988, 'A rhetorical analysis of Philippians and its implications for the unity question', Novum Testamentum 30, 57-88. https://doi.org/10.1163/1 $56853688 \times 00046$

Wead, D.W., 1970, 'The Johannine double meaning', Restoration Quarterly 13(2), 106-120. 